\title{
Political Ecology on Instagram Digital Media as A Politeness Branding Image
}

\author{
Fadhila Mazida $^{1^{*}}$, Riris Tiani ${ }^{2}$, Afidhatul Latifah ${ }^{3}$ \\ ${ }^{1}$ Faculty of Humanities, Diponegoro University, Semarang - Indonesia \\ ${ }^{2}$ Faculty of Humanities, Diponegoro University, Semarang - Indonesia \\ ${ }^{3}$ Faculty of Humanities, Diponegoro University, Semarang - Indonesia
}

\begin{abstract}
The convergence of technology has a major impact on human life. The dependence on media forms media ecology. Media ecology becomes a bridge in creating a group self-image. The main study of this research was to analyze the forms of politeness verbal messages on digital media @PandemicTalks. The Instagram account @PandemicTalks presents a new style of sharing information on digital media through graphic and visual content. The research orientation focused on visual verbal messages with the substance of COVID-19 related to the government policies. This qualitative research used both netnographic and descriptive phenomenological method. The results show that the COVID-19 Pandemic formed the characters of technology literate society. The communication lines were more dynamically interactive. Language was as a social and political control in creating the politeness branding image. The politeness strategy used the verbal wisdom markers. The sharing function politeness of visual verbal messages on the @PandemicTalks account was more dominant. The branding image used a persuasive euphemistic language style.
\end{abstract}

\section{Introduction}

The rapid development of technology also increases the use of social media, such as Twitter, Facebook, and Instagram. Nowadays, everyone has a smartphone to access social media anywhere and anytime. Social media can be considered as online media in which each user can easily participate in making and fulfilling the contents inside [1]. Social media have been defined in various ways [2]. Social media can be seen as the vehicle to represent self and group identity [3]. In addition, social media can also be used as an instrument to disseminate information, education, and entertainment both from and for the public. The presence of social media has made significant changes in the ways people communicate with each other and facilitated the accessibility of a virtual world 
through smartphones. Some social media users can politely behave and adjust to the conditions, although others still cannot [4].

During the COVID-19 pandemic, one of the social media, which is quite popular, Instagram, had a significant role since the users can disseminate news and personal experiences related to the pandemic. The active Instagram users in Indonesia have ranked fourth globally, ranging from 18-34 years old [5]. People can easily find the topics related to COVID-19 on Instagram in real-time and global. Some topics discussed health world conditions during the pandemic, the current research, lifestyles during the pandemic, ways of preventing COVID-19, and the pandemic impacts on various sectors. Various topics provided by Instagram have made the users well educated and understand that recently humans live in a health crisis. In addition, Instagram users utilize the Instagram platform as an instrument to campaign the danger of COVID-19 to educate the other users and reduce the spread of the viruses.

The utilization of Instagram as an education medium makes people quickly access essential information related to the pandemic. The Instagram account (a) PandemicTalks is one platform that is present to provide information and data around COVID-19 in Indonesia. This platform was initiated to disseminate the information related to the COVID-19 pandemic in more open and straightforward ways. Recently, the Instagram account @PandemicTalks have been followed by 233 thousand followers with more than 700 uploaded content.

The central hypothesis in this research deals with the politeness strategies used by the Instagram account @PandemicTalks in uploading the contents related to the COVID-19 pandemic. This study is classified inti qualitative research. Qualitative research generally obtains data from several sources through observation, interviews, and documentation [6]. Politeness shows how a speaker communicates and still considers the interlocutors' feelings [7]. When talking about politeness, strategy is a critical element in politeness. Based on the explanations above, politeness tends to reflect the speakers' attitudes to the interlocutors by paying attention to the politeness strategies [8]. Politeness strategies naturally appear in each interaction between speakers and interlocutors. By using these strategies, both speakers and interlocutors can understand without offending each other [9].

\section{Research Method}

This study is classified into qualitative research. The research data were in the form of content uploaded by the Instagram account@PandemicTalks. This research analyzed the politeness strategies used by the Instagram account (a) PandemicTalks in delivering the information related to the COVID-19 pandemic to educate and provide various explanations informing that this pandemic situation is still dangerous. The platform @ PandemicTalks also encourages people to continuously obey the health protocols regulated by the government since Indonesia has entered the New Normal era.

In this research, the researchers used both primary and secondary data. The primary data were collected by observing the contents uploaded by the Instagram account @PandemicTalks. The data were selected based on the number of likes and comments from the posts selected as data. Meanwhile, the secondary data were obtained from the literature studies, such as scientific articles and books 
related to this research. The collected data were then analyzed using the politeness theory developed by Brown and Levinson.

\section{Result and Discussion}

Today, anything can be created, copied, pasted, and shared with thousands of people online almost instantly [10]. Governmental and non-governmental institutions increasingly use social media as a strategic tool for public outreach [11]. One of the non-governmental organizations that used Instagram to communicate information on COVID-19 is the Instagram account called @ PandemicTalks. The following is a discussion of the @PandemicTalks post containing Levinson's politeness strategies.

Data (A)

Eling lan Waspada

Stay Alert.

Kematian Covid-19 Jateng Tertinggi 3 Hari Berturut-turut.

The death caused by the COVID-19 in Central Java is the higher within the last three consecutive days.

In this context $(\mathrm{A})$, the politeness strategy was shown in the negative politeness strategy with polite language in polite manners. In this case, the Instagram account @ PandemicTalkss, as the speaker expected all Indonesian people to stay alert (In Javanese expression known as eling lan waspada), warning that Covid-19 is still widely spread out there. In addition, the Instagram account @ PandemicTalks also reminded people that the death caused by the COVID-19 pandemic in Central Java was the highest in the last three consecutive days on 26-28 April 2021.

There was an increasing trend of Covid-19 cases in April 2021. This was also explained by the Director of the Directly Transmitting Disease Prevention and Control of the Indonesian Ministry of Health, Siti Nadia Tarmizi. Nadia stated that Indonesia had an addition of 600 COVID-19 cases at the end of April [12]. People should be highly aware since the government has not entirely given the vaccination to all Indonesian people.

The government always reminds all Indonesian people to obey the health protocols when performing any activity continuously. People have become tired and then result in poor implementation of health protocols. Poor implementation of health protocols encourages the increasing number of COVID-19 cases in Indonesia. The Indonesian government and people should mutually participate in decreasing the number of COVID-19 cases in Indonesia.

\section{Data (B)}

you deserve to have a space in this world

you are allowed to talk about your feelings

you are allowed to make boundaries

you deserve kindness

YOU CAN HEAL

Positive politeness strategies can be seen in data (B) which has a form of encouragement. The politeness markers in the data (B) show that the optimistic 
statement addresses the digital public. The message of enthusiasm and psychological building for the digital society appears in every verbal. Emphasis on positive politeness markers to provide an expression of psychological encouragement to the community digital is seen in the statement to have a space in this world; has a message that anyone on earth in Indonesia has the right to continue to receive health services in order to live. If there are families exposed to COVID-19, there is no need to isolate themselves because the government will readily monitor and provide full support for patients through health services in each district. Statements to talk about your feelings; has a message that people are welcome to express their opinions openly about their feelings while being part of the Indonesian soil to share their experiences regarding COVID-19. This verbal message is beneficial for the public because the information from various perspectives can be accepted by the community, for example, post-vaccination health conditions, the discovery of herbal medicines to increase antibodies, and others. In particular conditions, the government's firmness appears in the message to make boundaries, meaning that the freedom to convey aspirations through various public means is welcome but must carry out the Health protocol in an orderly manner. People have the right to impose restrictions on themselves if they are in the public environment or the home environment. Awareness of selfboundaries must grow in a secret society.

The government's branding image through the @PandemicTalks Instagram account is visible in the expression YOU CAN HEAL. The data (B) message shows that the government's trust in the Indonesian people can provide positive influencers for others. This branding image has a message that problems continue to develop in Indonesia through the data source https://covid19.go.id/peta-sebarancovid19 as of 18 May 2021 out of a total of 1,744,045 confirmed patients and 48,305 who have died. Indonesian society. The government will not be able to suppress the spread of COVID-19 if the self- boundaries of society are not developed.

Data (C)

Nekat mudik, sudah jauh-jauh malah disuruh putar balik.

Forcing to do homecoming may result in a pointless long drive as the COVID-19 On-Duty Officers will eventually force you to go back home.

The negative politeness strategy used in data $(\mathrm{C})$ is in the form of impersonal politeness. The expression found in data (C) was uploaded by the owner of the Instagram account@PandemicTalks, commenting on the Indonesian people who still force themselves to do homecoming during the COVID-19 pandemic. The speaker used the negative politeness strategy in the form of impersonal politeness. In the related post, no speakers and interlocutors were directly mentioned.

The Instagram account @PandemicTalks highly appreciated the COVID-19 on-duty officers in the field. They have tried to ask those forced to do homecoming to go back home as the pandemic situations in Indonesia have not been in better conditions. Some parties even said that if the Indonesian people are still forced to do a homecoming, the COVID-19 cases in Indonesia may worsen more than in India. 


\section{Conclusion}

Based on the analysis results, most contents uploaded by the Instagram account @.PandemicTalks use the negative politeness strategy. The communication lines were more dynamically interactive. The politeness strategy used the verbal wisdom markers. The sharing function politeness of visual, verbal messages on the @PandemicTalks account was more dominant. The branding image used a persuasive euphemistic language style.

\section{References}

[1] Maulinda, Ririn, and Suyatno. Communication Ethics in Utilizing the Social Media (Instagram). South Tangerang: Online Journal Systems UNPAM (Universitas Pamulang) . (2016).

[2] Wolf, Maxim, Julian Sims, and Huadong Yang. Social Media? What Social Media? Proceedings 2018 UK Academy for Information System Conference. United Kingdom. (2018).

[3] Matley, David. 'This is NOT a \#humblebrag, this is just a \#brag": The pragmatics of self-praise, hashtags and politeness in Instagram posts. Discourse, Context \& Media 22 page 30-38. Switzerland: English Department University of Zurich. (2018).

[4] Mulyana, Ahmad. Civility on Social Media (The Tendency of Politeness Level of Internet Users on Social Media). Repository Universitas Mercu Buana. Jakarta. (2015).

[5] Damayanti, Annisa, and Kapat Yuriawan. Instagram as One of Communication Media related to the Risks during the COVID-19 Pandemic: a netnographic study on KawalCOVID.id online Community. Journal of Development Communication Vol. 18 (02) 2020 pp. 176-193. Jakarta. (2020).

[6] Idaman, Nur dan Woro Harkandi Kencana. Teen Virtual Identity on Social Media Instagram. Jurnal IKRA-ITH Humaniora Volume 5 Nomor 1 Bulan Maret 2021. Jakarta : Persada Indonesia University YAI. (2021).

[7] Brown, P., \& Levinson, S. C. Universals in language usage: Politeness Phenomena. In Questions and politeness: Strategies in Social Interaction (pp. 56311). Cambridge University Press. (1978).

[8] Hu Yuheng, Ali Tafti, and David Gal. Read This, Pelase? The Role of Politeness in Customer Service Engagement on Social Media. Proceedings of the $52^{\text {nd }}$ Hawaii International Conference on System Sciences. Chicago: University of Illinois. (2019).

[9] Ayuningtias, Diah Ikawati. Politeness Strategy in Request: Does it Always Work Well? Madura: Universitas Trunojoyo. (2012).

[10] Martin, F., Wang, C., Petty, T., Wang, W., \& Wilkins, P. Middle School Students' Social Media Use. Educational Technology \& Society, 21 (1), 213-224. (2018).

[11] Mika A, Khan M.L., Quan-Haase A. Public health agencies outreach through Instagram during the COVID-19 pandemic: Crisis and Emergency Risk Communication perspective. International Journal of Disaster Risk Reduction Volume 61, July 2021. (2021).

[12] Puspita, Ratna. "Kemenkes : Indonesia Perlihatkan Indikasi Lonjakan COVID-19", Republika, 
https://republika.co.id/berita/nasional/umum/qsetkl428/kemenkes-indonesiaperlihatkan-indikasi-lonjakan-covid19. (2021). 